Drunk on Capitalism. An Interdisciplinary

Reflection on Market Economy, Art and Science 
EINSTEIN MEETS MAGRITTE: An Interdisciplinary Reflection on Science, Nature, Art, Human Action and Society

Series Editor

Diederik Aerts, Leo Apostel Centre for Interdisciplinary Studies, Brussels Free University, Belgium

For further volumes:

http://www.springer.com/series/5914 
Robrecht Vanderbeeken - Frederik Le Roy

Christel Stalpaert • Diederik Aerts

Editors

\section{Drunk on Capitalism. An Interdisciplinary Reflection on Market Economy, Art and Science}

是 Springer 
Editors

Robrecht Vanderbeeken

Faculty of Fine Arts

University College Ghent

Jozef Kluyskensstraat 2

9000 Ghent

Belgium

Robrecht.Vanderbeeken@UGent.be

Christel Stalpaert

Department of Art, Music \&

Theatre Sciences

Ghent University

Blandijnberg 2

9000 Ghent

Belgium

christel.stalpaert@ugent.be
Frederik Le Roy

Department of Art, Music \&

Theatre Sciences

Ghent University

Blandijnberg 2

9000 Ghent

Belgium

Frederik.LeRoy@UGent.be

Diederik Aerts

Leo Apostel Centre

for Interdisciplinary Studies

Brussels Free University

Krijgskundestraat 33

1160 Bruxelles

Belgium

diraerts@vub.ac.be

ISBN 978-94-007-2081-7

DOI 10.1007/978-94-007-2082-4

Springer Dordrecht Heidelberg London New York

Library of Congress Control Number: 2011939208

(C) Springer Science+Business Media B.V. 2012

No part of this work may be reproduced, stored in a retrieval system, or transmitted in any form or by any means, electronic, mechanical, photocopying, microfilming, recording or otherwise, without written permission from the Publisher, with the exception of any material supplied specifically for the purpose of being entered and executed on a computer system, for exclusive use by the purchaser of the work.

Printed on acid-free paper

Springer is part of Springer Science+Business Media (www.springer.com) 


\section{Contents}

Single Step Guide to Success - Day Planning.

Heath Bunting

Part I Science for Sale

The Inseparability of Science and Values

John Dupré

The Humanities Under Fire?

Hendrik (Rik) Pinxten

What Is There Beyond Mertonian and Dollar Green Science?

Exploring the Contours of Epistemic Democracy....

Jeroen Van Bouwel

Enclosing the Academic Commons - Increasing Knowledge

Transfer or Eroding Academic Values?

Sigrid Sterckx

(E)valuating Words: Money and Gain in the Therapeutic Economy

Dany Nobus

Copyright: A Curse or a Blessing?

Evi Werkers

\section{Part II Buy Buy Art}

The Fethish Character of the Work of Art and Its Secret.

Frank Vande Veire

Salvador Dalí's Dream of Venus at the 1939 New York World's Fair: Capitalist Funhouse or Surrealist Landmark?

Christel Stalpaert 
How to Sell a Boring Action Hero: An Analysis of the Success of The Bourne Ultimatum Within the Context of Corporate Hollywood

Isolde Vanhee

Saturn and His Children. The Crying of Potential Estate:

A Case Study of the Art Market as Metaphor and Practice

Katerina Gregos

The Work of Art in the Age of Meta-Capital

Christophe Bruno

How to Handcraft an Achingly Self-Referential Virtual

Commodity Fetish Object (For Fun and Profit!)

Julian Dibbell

Index 